\title{
Is Lord Acton Right? \\ Rethinking Corruption, Democracy, and Political Power
}

\begin{abstract}
Herbert H. Werlin
Herbert $\mathrm{H}$. Werlin is a retired professor from the University of Maryland, USf and was a researcher, writer, and editor for the World Bank and other international anizations. $\mathrm{He}$ is the author of The Mysteries of Development: Studies Using Political Elasticit, eory, University Press of America, 1998/2001.

Winner, 2010 Fred Riggs Award, American Association of Public A minist"ation

E-mail address: werlin@crosslink.net

This article examines Lord Acton's famous asser on, "power tends, 10 corrupt and absolute
\end{abstract}

\section{ABSTRACT} power, to corrupt absolutely," including the suggestion t t democratiz tion reduces corruption. This assertion requires us to look at the meaning of political p r, corrupti $n$, and democracy. By making a distinction between primary and secondary corruption (a tiallv controllable and uncontrollable corruption) and between liberal democracy (emp ino competruve politics) and classical democracy (emphasizing consensus-building politics), togeth Wry adycing Political Elasticity (PE) theory, a number of difficult questions are raised: 1 . What is atical ower (with Hobbes and Russia, in mind)? 2. What is the linkage between politi wer and corruption? 3. Why is it that corruption does not necessarily prevent economic deve opmer (with $\mathrm{Cl}$ in mind)? At the conclusion the autocracycorruption linkage is examined as $\mathrm{mp}$ the hy a comparison of Singapore and Jamaica, indicating: (1) that political power, if pe sumive not necussarily corruptive; (2) liberal or partisan democracy tends to corrupt and law democras to corrupt absolutely and (3) authoritarian regimes may recognize that controllip, con tion is essy alal for their legitimacy and economic prosperity.

Keywords: Lord Acton; political p y corruption; democracy; authoritarianism

abou cton's ous assertion, "power te
corrup and werces ys to consider a series of
Let us bes with the most basic question of all:

\section{WHAT IS POLITICAL POWER}

In turning to the question raised by Lord Acton regarding the linkage of political power to corruption, we have to improve our understanding of political power. Instead of the coercive view of political power prevalent in political science literature ("A has power over B to the extent that he can get B to do something B would not otherwise do," to quote Robert Dahl $(1964,50)$, it has to become more persuasive for political development to take place, 
recognizing that, while A can force B to surrender resources, he/she cannot force B to productively invest them. This requires an "enabling environment," which must be fostered, rather than overtly imposed.

The paradox of a dictatorship that is powerful enough to undermine potential forms of opposition and political independence stemming from the legislature, the judiciary, the communication media, political parties, interest groups, and the bureaucracy itself and yet too weak to improve living conditions or stimulate widespread economic development is presented in Richard Sakwa's 2004 book on Russia.

While, on the one hand, there has been an "authoritarian centralization of power" on the other hand, Putin has "not been able to build a state strong enough to prosecu orga d crime and stamp out corruption." This leads the author to suggest (pp. 245, 247 hat there been "the birth of a new Leviathan in Russia;" but this is "based more on a ttempt maintain artificial stability rather than reflecting an organic order." Consequ governmental institutions are too weak to deal with such prob vs as apita ight, concentration of ownership, protectionism, weak or lawless co or s, and xtensive poverty and misery.

To understand why it is that the creation of a poli cal eviathan often leads to political weakness rather than strength, it might be useful o back Hobbes's argument for despotism and for Leviathan, as explained by Sheld n Worin in his 60 book (257-285). Hobbes was especially concerned with the dangers $f$ anarchy associated with the religious conflicts of seventeenth-century England. This le him to the fiew that "the blessings of peace are assured only when society is in total sub) ion to a absolute authority" (Wolin 1960, 266). This meant that it was in the rest of en ne to agree to obey a common authority, to "reduce all their wills, by pl ratr. vvoices, unto one will;" to give the Leviathan the authority to impose religious on surrender the right of selfprotection (Wolin 1960, 265). In 1 it was he responsibility of the Leviathan to provide equality of treatment, fairness, a the ondition lor prosperity and contentment, in addition to security. Yet, according to wo political power was a grossly oversimplifi a, cven "low, one." In other words, political power, for Hobbes, was essentially a vague - ept. Wea 1 d private property were to remain in private hands. Inasmuch as these fo ns o. ver remaned in private hands, we have a picture of a "mighty Leviathan" as not' more th. "mere spitfrog" (Wolin 1960, 285).

In thinkig abct Hobbes. Leviathan, we might also point out the extent to which political poy o b mear ingful, must function through institutions. We pay property taxes, for example, lar becau of the trustworthiness of institutions responsible for registering our $\mathrm{p}^{\mathrm{p}}$ com va ating with us, determining value and amount, transferring funds, enf ing lyments, preventing misuse of public funds, etc. As these institutions are under ctiveness of political power is clearly reduced. In Kenya, when the bwana kubwa (people) were reported in the 1980s to be avoiding property taxes and service charges, th wana kidogo (poor people) who had benefited from a World Bank project here, successfully resisted paying them. In Onitsha, Nigeria, officials during the 1980s threatened to cut off water supplies to those failing to pay property taxes. However, since services were unreliable and mismanaged, taxpayers considered the threat meaningless (see Werlin 1998/2001).

Using the writings of Max Weber and Hannah Arendt, Goehler (2000, 40-68) suggests an important distinction between transitive political power (referring to the authority of an individual) and intransitive political power ("social energy," as I would define it.) To the 
extent that intransitive (institutional) political power is viewed favorably, manifestations of transitive (personal) power appear to be benign, desirable, and functional, thereby helping to explain why large public sectors and neo-corporatist structures do not necessarily result in massive corruption. For example, the Dutch Minister of Housing, Physical Planning and Environmental Planning can, not only supervise public sector and private sector use of land, but also control local zoning boards; force neighboring jurisdictions to cooperate, change boundaries to facilitate planning and equalize taxation; or prevent businesses and wealthy individuals from playing off one jurisdiction against another (see Hamnett 1985, 21-42). However, this manifestation of power is not viewed negatively because of the legitimacy of political and administrative systems. As explained by Toonen and Hendriks "Dutch society seems relatively content to trust the self-regulatory nature of the ower-shar save energy for other purposes."

The objective of Political Elasticity (PE) Theory (which is here briefl edmm is 0 link transitive to intransitive political power (see Werlin 1998,2001, Wer in 200 his suggests that political power takes a different form in More Developen un thes th $\mathrm{n}_{1}$ Less Developed Countries in that it is more elastic in two meanings of anten por er can be delegated or decentralized without being diminished or dam (in the $\mathrm{m}$ of a rubber band) and that it can affect in a predictable way (in the form f a on) pub c behavior. As it does so, it generates greater "social energy." Politic clastici, lepends partly on the selection of appropriate political hardware (includi g "objective" Ins of organization, regulation, procedure, and technology) but mostly the enhancement of political software (i.e., policies and practices that foster respectful rela ns between leaders and followers). The effectiveness of political software is directly pro ional governmental success in establishing acceptable goals, hiring quali nersonno, ml couraging training, delegating responsibility, stimulating motivation and co per. naying attention to morale, expanding two-way flows of communication, promoting ama, maintaining supervision, cultivating contractors, protecting independer eres of uthority, and developing conflict resolution procedures. Inasmuch as a goy nmen fails to o any of these commonsensical requirements (with appropriate variations its orm both micro-and macro-administration are going to be problematic. Yet, progi can be measured on the basis of steps taken to improve any aspect of these regr $A$ ents

Dennis Wrop 1979, points out that some scholars do not regard persuasion as a form of power b-cause they equ "power with the capacity to compel obedience in the face of opposition In fa coercion without persuasion is likely to be ineffective because it indicates a pou ality o political software. While political software requires a series of commo ical it by no means an easy or inexpensive process. In this regard, Peters (199' 153 quotes $O$. Key to the effect that "the average voter is no fool; he or she gerc $\mathrm{V} y$ dantands what is being done with taxes and services." In 1998 (according to a 2001 D report), Swedes were the most heavily taxed people in the world, with tax receipts a nting to 52 percent of GDP (about twice the European Community average); but their willing ness to pay this amount stemmed from their belief that they were receiving "a fair return in services for their taxes" (Peters 1991, 160).

In seeing political power (with PE theory in mind) as a form of social energy, we can deal with the suggestion that political power is somehow evil as well as dangerous. As we examine assertions about political power, we have to recognize the long history of hostility towards it. According to Hobbes, "there are very few so foolish, that had not rather govern themselves, than be governed by others" (quoted, Wrong 1979, 237). Dr. Johnson expressed this hostility more humorously in noting that no one is ever "innocently employed when 
exercising or seeming to exercise power" (quoted, Wrong 1979, 250). Animosity towards political power strangely unites the extremes of left and right, going from Herbert Marcuse's utopian anarchism to the advocates of complete deregulation ("let the market rule"). Between these extremes is the position that while politics is a "struggle for power," it is also a "struggle to limit, resist and escape from power."

Dwight Waldo (who died in October, 2000, to the dismay of his students, including myself) never lost his mixed feelings about administration. He argued (p. 219) in his 1980 book, The Enterprise of Public Administration, that the "enterprises of civilization and administration have from the beginning been intimately joined, each sustainino and stimulating the other." However, as did Max Weber, Waldo feared what he beliey ca to o inevitable triumph of bureaucracy because it seemed to be so undemocratic "e frequen quoted Weber's famous threat: "The bureaucratic organization is, together h lifele machinery, about to produce the iron cage of future serfdom in which $p$ en will ho helplessly like the fellahin in Egypt..." (Waldo 1980, 139). Yet, \& ucces yl den cracy requires an efficient and effective bureaucracy to prevent secondary or in.

As indicated in this article (using PE theory), I sugge why it is at contrary to Weberian theory, effective bureaucracies cannot be altoget or $\mathrm{h}$ mocratic. 1 here must be some consensus-building (i.e., classical democracy) fo a lequat olitical software and, thereby, political elasticity to result. Consequently, ne ner auministrat hor political leaders can simply impose their will to attain the political ela icity essential for the Weberian goals of precision, speed, certainty, continuity, and impartial Instead, t ey must consider the needs and desires of subordinates and followers. Unless po powe is persuasive, more may be less. Moreover, insofar as political power is tirely cocm, it is also corruptive (inevitably undermining political software), as Lord Act pow observed. But not necessarily so if it is persuasive. While leaders can "persuade" eple ty be corrupt, they cannot in this way generate the social energy essential olitical levelopment because the required institutions cannot be built upon untrustwort y fou lations. Mericans view a "separation of powers" as a good thing; not so, in much o we political power has an "all or nothing" connotation. In other w ads, ins tional arrangements to divide power (including an independent legislature judiciary mbined with forms of federalism) are viewed as "weaknesses" (regarc ss o fact that they actually give legitimacy, and, as such, strength to the political sys

\section{WHAT K OR AOPT ON?}

Semor Bar Oba a delivered a lecture in August, 2006, at the University of Nairobi in $w^{\mathrm{l}}$ ich h sugges hat corruption was "robbing people of the opportunities they fought for. the ame time, he admitted that his own city, Chicago, "has been the home of the most corrup car porncs in American history over the years." The difference is that various factors (h established public interest groups, the free press, the two-party system, Federal Bureau of nvestigation and Justice Department agents, departmental inspectors, public attorney investigations, the judicial system, etc.) exist in Chicago but not Kenya to control manifestations of corruption.

For this reason, I believe that it is useful to make a distinction between primary and secondary corruption. Primary corruption (as exists in wealthy countries where often governmental money, favors, or power are misused for private gain) is when institutions are strong enough to keep corruption under control; secondary corruption is when this is not the case. Secondary corruption (as exists in most poor countries) would be analogous to a 
basketball game in which the referees are corrupt, so that it is not only necessary to foul, but also to pay the referees to facilitate the fouling. Consequently, the concept of "fouling," as an action disallowed by the rules, becomes no longer meaningful insofar as "payment determines the rules." Likewise, secondary corruption is not seen as "shameful" but, rather, as "standard operating procedure." As such, it becomes a form of "political illness," which Bill Gates must confront if he (along with his foundation) is to really overcome Africa's medical illnesses.

The extent to which Kenya suffers from secondary corruption is indicated in a 2003 World Bank report on Kenya. Among the factors indicated for corruption include: weak financial management and procurement systems; inadequate resources for watchdog institutions such as the office of the controller and auditor general; conflict of intera. $y$ allowing civil servants to engage in private businesses; and toleration of $\mathrm{s} 1 \mathrm{ll}$ bribes provision of services. Moreover, not much improvement can be expected yhen rts of tl auditor general are usually several years out of date and those identifie in these orts as "wrong doers" are seldom prosecuted and hardly ever convicted (Wor) Bank 3 3, 94

When Daniel arap Moi came to power in 1978, he seemed to in ted in omoting constitutionality, the rule of law, open elections, and a relative free press. wa ver, it soon became clear that, for Moi, as for Jomo Kenyatta, politics neas the purst $/$ of profit, the creation and maintenance of personal followings, and the rering vors from those above in order to enhance one's position" (Miller and Yaege 1994, 119). Lérial resources were used to manipulate parliament, local government, pu lic opinion, and the judicial system. As of 2002, Transparency International ranked Kenya hong the $\mathrm{m}$ st corrupt countries in the world, with only five other countries (out of a tota 102) b low Kenya in its corruption perceptions index. How much Kenya has as a resu corruption is indicated by the Goldenberg export compensation scandal wh cir the country in 1991 about a fifth of its gross domestic product. According to a 2002 fonmis on of Inquiry, President Moi himself was directly implicated, along wit two so s, his daughter, and a large number of high ranking officials (Karanja 2001 03). aring th Moi regime (1978-2002) corruption became so bad that the IMF froze fun int.

When Mwai Kibak bocam resident in 2002, he promised a "zero-tolerance on corruption.” In support o is promis c IMF gave Kenya in 2003 a \$252.75 million dollar loan to fight povert and next yes, the World Bank approved 263 million dollars for development proj in trans agriculture and water sectors. Yet, the resignation of the anti-corruption advis John Git ongo, in February 2005 indicates the difficulties encountered when "the ki. ns occurr otion" operate within the top levels of government (Mulima 2005). Both the Nation. Securit Minister and the Finance Minister were allegedly involved in paymens about molion dollars to a shadowy foreign firm for terrorist proof passports and uipm at for cri rinal investigation.

allegation by the British ambassador to Kenya in 2005 that the country had lost 187 million dollars since Kibaki came to office, the European Union suspended 50 million aro in budget support. As explained by Sahr Kpundeh (a World Bank public administration analyst) corruption in Kenya serves "as the glue to hold the system together, allowing subordinates and close allies to embezzle public resources in return for loyalty and support" (Kpundeh 2004, 264).

Many of the criminal gangs, which are associated with the most serious forms of illegal activity, have police among their members and even leaders. Considering that police officers start at a salary of only $\$ 61$ a month, this is understandable. According to the 2003 State Department Country Report on Kenyan Human Rights Practices (2004, 7-10), it is a common 
practice for police to invade homes looking for firearms and then to steal valuable items unless bribes are paid. People are often arrested with the sole purpose of extorting bribes. A 2005 Transparency International study found urban Kenyans to pay nearly 20 percent of their average monthly income to the police (World Bank 2003, 95). This report goes on to list the police as the most corrupt of all the institutions surveyed.

The corruption and inefficiency of the judiciary are contributing factors in this regard. While a high percentage of judges were accused of corruption in 2003, no legal charges were filed against any of them that year. Because of the inefficiency and corruption of the legal system, at least 60 percent of the prison population consists of pretrial detainees, with some having been in prison for many years under miserable conditions.

Politics is often thought of as "partisanship" - the struggle for competitiy dvantage. so, why should we not consider corruption as nothing more than a manifectation fpolitic Maya Chadda $(2004,136-7)$ suggests that political scientists, using the urrently to iona le concept of "rational choice," might see corruption as merely "ex ssive nt-see "g" maximizing opportunities to enhance wealth, status, and power. $\mathrm{Ho}$ ve rolitics temming from the classical Greek word, "polis" - community) also re ers to " esma ship" and "governance." It is the conflict between the two sides of politi s seems to at issue here. Indeed, one can see corruption as "the challenge of partisans, p to ssmanship" or of "greed to governance." As an analogy, we might see di cas as the nlenge of harmful microorganisms to the health of the body, with le resulting feve as an indication of "corruption" (bodily decay in its original meaning).

\section{WHAT IS DEMOCRACY?}

Lord Acton's assertion suggests that de row should reduce corruption. A 2005 book by Morton Halperin, Joseph Siegle, and ir ael einstein starts out with a strong case for democracy in raising living sta $\mathrm{s}$ : imp ving health, education, and food production; generating superior levels of so al w fare; ma raining higher levels of economic growth; and escaping economic collarso di vol, in later sections of the book, the authors do have some reservations. "Aections, isolation," they point out (p. 61) "do not contribute to improved development ding: " $\mathrm{N}$ that hold elections, yet have weak institutions, display significantly wer nomic gowth and social welfare than democracies with strong institutions."

The fac $\mathrm{rs}_{\mathrm{s}}$ that re thereby required include: a free press, an independent judiciary, a meritocratic c1 vice, a independent private sector, standardized accounting and auditing norms, stang opp tion olitical parties, a vibrant civil society, an anti-corruption office, an indep onder central $\Lambda$, etc. Because of the importance of strong institutions (as against con itiv alections) the reader might find the following sentence (p. 57) confusing: "while the Eas sian cxperience demonstrates that democracy is not indispensable for development, the distin aness of the conditions that have fostered economic growth in its absence need to be recogniz,d." Indeed, how exceptional is the economic development of the East Asian regimes? After all, most European countries developed economically long before they could be considered democracies.

Returning to our earlier presentation of corruption, we can similarly make a useful distinction between classical democracy and liberal democracy. Whereas liberal democracy has to do with partisanship (elections, multi-party systems, and majority rule), classical democracy refers to the Athenian conception of community or polis: emphasizing statesmanship and consensus-building. Most scholars and journalists, on the other hand, 
recognize only a liberal conception of democracy. Yet, in the absence of statesmanship, elections appear much like an Olympics without the necessary conditions for sporting events and rules for participating, competing, and officiating. If nothing else, the American presidential elections of November, 2000, have shown us the importance of judicial decisions in determining the outcome. Consequently, it became a matter for lawyers, not generals.

In countries with strong social divisions, political parties (if allowed) tend to generate violence rather than compromise. It is common for politicians everywhere to arouse racial, ethnic, or religious animosity to generate political support. Countries, such as Yugoslavia, Sri Lanka, Rwanda, and, most recently, Kenya (to name just a few) functioned reasonablv well under colonial or authoritarian rule before political liberalization tore them aratt. in Islamic world, the struggle for democracy is combined with a struggle for secy ism, maki elections (as in Lebanon, Iraq, Palestine, Algeria, among many others)

The linkage between democracy and the rule of law is well erablished in nas Carothers's 2006 book, Promoting the Rule of Law Abroad, emph ng jormp rto ice in protecting individual rights, facilitating a modern market economy ro ring the authority of the people. He points out that, while more than a billion do rs from do or d countries and international organizations since the beginning of the $19.0 \mathrm{~s}$ ticularly 1 th the end of the Cold War) has gone into these efforts, the results large various reasons, including: (a) oppressive government are tearful of cermining their own authority; (b) the goals of predictability and efficie cy often conflict with the needs of the disadvantaged; (c) legal reform tends to be seen as t hnical rathe than political; (d) equality before the law conflicts with the need to maintain $\mathrm{p}$ or base upon ethnic, religious, and economic considerations; and (e) some as ts (e.g., ... vement of security forces and legislation) often prevail over other aspects e.ondling of trials and implementation of reforms). Anyone reading the recent news fron $\mathrm{Ir}_{\mathrm{q}} \mathrm{ca}$ appreciate such difficulties as how to improve the functioning of law-enf nent w hout contributing to inter-ethnic violence and how to conduct efficient and eff tive als unde onditions of civil strife.

Political leaders, regardes $t^{1}$. ind of their power, must maintain the support of such powerful groups as "re milita the civil service, large business owners, trade unions, and journalists. Often $t^{1}$ groups à ore interested in rent-seeking opportunities than in anything else. The ci 1 see for exple, is likely to oppose the curtailment of its power through privatizat ceregula glimination of central planning, and reduction in the work force. The mor dem ratic a go crnment is, the more it is expected to use a participatory and consultative on act it is difficult to use such an approach in justifying such requisites for reform as do izing th civil service, reducing consumer subsidies and scholarships, cost recove y, yatiza a a trade liberalization.

the contelisti nature of politics, within which leaders view the public sector as their person. roperty and consider loyalty to be more important than competence, does not change with eled $\mathrm{T}$ This is so because leaders are more concerned with survival than with developmen. Consequently, jobs, contracts, and favors are given to those linked to powerful ethnic groups, families, and police or military officers. Such a feudalistic system usually undermines effective administration.

\section{WHAT IS THE LINKAGE BETWEEN POLITICAL POWER AND CORRUPTION?}

The complexity of the autocracy-corruption linkage may be apparent from a comparison of democratic India and authoritarian China, both of which have been growing by more than 
eight percent annually in recent years (see Yusuf 2006). While Transparency International suggests that levels of corruption are similar in these two countries, Chinese institutions appear to be much stronger than Indian ones, indicated by World Bank (2000/2001) statistical comparisons. Whereas between 1993 and 2004, the percentage of India's population living on less than $\$ 1$ a day fell from 42 to 35, it fell from 28 to 11 in China. Nearly half $(45.5 \%)$ of India's population were illiterate during the $1990 \mathrm{~s}$, as again $18.3 \%$ in China; and less than half $(48.9 \%)$ reached secondary school, in comparison to $61.4 \%$ in China. Less than half (45 $\%$ ) of Indian women are literate, as against $87 \%$ in China. India's expressway mileage is onetenth that of China. Most (61\%) of Indian factories need their own generators, compared with $27 \%$ in China, and the cost of power is $40 \%$ more expensive. China can spen on infrastructure and public services than India, not only because its economy is mu n larger (2 $\%$, but also because it is able to collect twice the percentage of GDP in ta $(19 \%$, against only $9 \%$ ).

Yet, it is clear that there is a linkage between autocracy and $c$ ruptio in Ch. (see Mann 2007). While China is no longer as overtly oppressive as wa th the cultural Revolution period, organized political opposition, a free press, nd an in ender judiciary are still disallowed. There are only 122,000 lawyers in Chi a its 1.2 b on people (as against nearly 200,000 in California with 37 million pec le), a they face persecution, including prison or loss of their jobs. Consequently, the not muc prevent the types of corruption described by Minxin Pei of the Carnegi Endowment (20,5), amounting to an estimated ten percent of government spending an three percent of the Gross Domestic Product.

Everything controlled by the state (1) land an wlions, contracts, appointments, etc.) requires some sort of bribe, with an e inm half of officials involved. While press coverage is given to apparently severe punishn tor to cials in high profile cases, "the odds of an average corrupt official goino il are a most 3 out of 100, making corruption a highreturn, low-risk activity" (Pe 200, 4). Ma Aestations of corruption have obviously intensified problems of erv discrimination against ethr c minon s and rural migrants, inadequate health care, low quality of products and service

However, corm ion a not appear to be of great concern to foreign investors. In the words of the Gl obar Advice $\mathrm{f}$ ork (2008), "foreign investors are not being scared off" by obstacles pos by c ruption, hcluding the need to make "facilitation payments" to have things done. seems be happening, according to James Mann (2007, 107), is that Chinese anxials ous to protect foreign investors from the worse manifestations of corry tion o keep estment dollars, euros, and yen flowing into the system," with the resu at are is "alegal system that offers special protection to foreign investors but not to ordina, Ninese mdividuals, much less to targets of the regime such as political dissidents or Tibetan a ists." Nevertheless, ordinary Chinese businesspeople do benefit from the fact that China ranks relatively well on a regional and international basis in regard to many aspects of doing business, such as cost of starting and closing a business, registering property, and trading across borders.

They also clearly benefit from the massive expansion that has taken place since the 1990s in the expressway network, rural roads, railroads, aviation facilities, and seaport capacity, despite the destruction of villages and the forced relocation of thousands of residents. 
In Philip Pan's 2008 book about China, he points out how difficult it is to fight corruption when all the governmental institutions seem to favor it: the trade union, the state media, the police, the courts, the prosecutors, etc. Yet, there are various factors that occasionally have reduced manifestations of corruption (e.g., having to do with rural taxation, internal passport policies, and eviction without adequate compensation): (1) the unwillingness to confront persistent public demonstrations; (2) the need to protect the free enterprise system; (3) the inability to control the internet and independent newspapers; (4) the desire to discipline irresponsible officials and (5) the recognition that "crony capitalism" must also be profitable. Nevertheless, "the political system is stuck in the past, with party officials struggling to preserve their power and privileges" (Pan 2008, 321). Why "crony capitalism" dysfunctional in China than in Russia is indicated in a story in The Economist ( 1 ne 28, 20 21-22) having to with the Triangle Group (a state owned radial tire-manara ring firm noting that, in its determination to be internationally successful, the gover ment hinstall excellent leadership, world-class manufacturing equipment, and care al att ntion a/ery detail of operations.

\section{CONCLUSION: SINGAPORE AND JAMAICA}

A social scientist comparing Singapore and Jamaiaa n the rly 1960s (each with a population then of about 1.6 million and a GDP per cap \$400), Great Britain was looming, might have predicted a $\mathrm{p}$ ach brighter futu for Jamaica, despite the dysfunctional impact of colonial rule and racial t sion (see Ncrris 1962). In 1960 Jamaica was the world's primary source of bauxite and lumina. is Industrial Development Corporation was responsible for 30 factories and ovo anufactured items. While its agricultural exports consisted largely of such tion products as sugar, bananas, citrus, and coconuts, it was promoting various exotic fry a spices, suitable for smallholder production. The country's beauty gave it treme dous potential as a tourist center, particularly after the Cuban revolution. At $t^{1} \mathrm{e}^{\mathrm{S}} \mathrm{Sa}$ time, ingapore had no natural resources and was suffering from severe racial, $r$ ous, nd politi al turmoil, intensified by its 1965 separation from Malaysia (see Lee Ky

The situation now f course, very different, indicated by the great disparity in per capita income (see W rla nk 2001, 4-5): Singapore, nearly \$30,000; Jamaica, less than $\$ 4,000$ (as of $200^{\wedge}$. While gapore's government has been able to eliminate persistent poverty, unemp syment, and c. Jamaica's government has not been able to break the linkage betw higb Jenage pregnancy rates (40 percent), female-headed households (40 percent), schoo p-out a 1 failure rates (one-third of those from poor households), poverty (one-thim the latis 1 ), and extremely high rates of ordinary and violent crime (Human and ocial evelops at Group). The departure of the most educated and qualified people (esth an an $80 \%$ of university graduates) to Europe and North America is particularly trouble e. Wnereas Singapore has been able to undertake some of the world's best programs wolic housing, public transportation, urban planning, public health, and public education, Jamaica's efforts to improve living conditions have largely failed.

Yet, Singapore cannot be considered a liberal democracy inasmuch as the government has used a one-party system to suppress dissent, detain without trial, intimidate newspapers and radical trade unions, enact anti-democratic laws and administrative regulations, and undertake "pork-barrel politics" to discourage opposition. Most recently (May, 2008) the "bankrupting libel suit" has been employed against the leaders of the Singapore Democratic Party. As explained by Mutalib (2000, 117), "an illiberal, (soft) authoritarian form of governance is certainly preferable to liberal democracy" because "economic growth demands 
much sacrifice from the people" which they might not be willing to support if given a chance. The resulting ambivalence towards democracy can be found in Lee Kwan Yew's memoirs (2000, 346, 606). Whereas in 1992 he proclaimed in the Philippines that "what a country needs is discipline more than democracy," he pointed out to a Chinese delegation to Singapore that year "that social control could not depend on discipline alone," adding: "People had to have a decent life with reasonable housing and social amenities if they were to lead moral and upright lives. They had to accept the basic principles of our system of government."

In a case study of Singapore's public housing program, government officials appeared to be remarkably responsive to changing needs and demands and willing, not only to listen to criticisms and suggestions, but also to fund research on existing and emerging ms (Werlin 1998/2003). While Mutilib (2000) strongly (and rightly) suggests ty at Singap should move towards more liberal democracy, he reports on the willingness of th overnme in 1998 to revise its economic policies, taking unusual steps to swing pub a opin in fay of radical reform. During a recession in the mid-1980s, employees ey of rofita $\mathrm{ms}$ agreed to a significant reduction in salaries as a result of a "tripo "anso council composed of representatives of government, employees, and lab San and Fot 1996, 61).

This was facilitated by "vocal and frank comment on $11 \mathrm{pu}$ policies/carried out in the press, parliament, public forums, and grass roots instit ons." Lu vise, in response to the 1998 Asian financial crisis, the Parliamentary d signated Comn ce on Singapore's Competitiveness made a number of painful recom endations which were acceptable only because of the existing high quality of political sof are, includ hg considerable respect for the integrity of public administration.

In a book that is quite critical of au itarian rum Singapore, one of the authors (Neher 1999, 51), points out that "Singapor dou invsubstantive democracy," including due process of law, equality of opportunity, 10 "a y odicum of civil liberties." Professor Larry Diamond ( 2006), a leadip erican xpert on democracy, describes Singapore's political system as a "hybrid" comb ing mal formal elements of democracy (including multiparty electoral competition limited coercion in daily life) with many practical and subtle eleme is or aut cy.

Jamaica, in cont a Singapo maintained a vigorous two-party system since independence, with e Pa 'e's National Party and the opposition Jamaica Labor Party alternating in poy crabout evo ten years. However, both political parties regularly employ criminal gang (assis do som extent by police and civil servants) to mobilize political support, dism f vors, nd intimidate opponents (see Figueroa and Sives 2002, 99-100). The civil servic he jud cial system, and the police have lost citizens' respect as their effecticen has a andermined by inadequate pay, training, expertise, and even drug mo (Gr , 2003, 0). The most recent Transparency International report (2007) finds Jaman agressed in regard to corruption, scoring 3.3 out of 10, as against a 2006 score on Next to Guyana, it is considered the most corrupt of the English-speaking Caribbean antries. Singapore, on the other hand, has a 9.3 score, thereby increasing the respect for its governmental system, even among those who resent its authoritarianism.

According to The Economist (November 1, 2003, 36), extortion by gang leaders adds 40 $\%$ to project costs, amounting to "an official tax of perhaps $\$ 100 \mathrm{~m}$ a year," further encouraging violent turf wars between rival gangs and contributing to debt, which "eats up 60 $\%$ of Jamaica's tax revenues." Businesses must not only pay kickbacks and bribes, but also "there is pressure to employ workers and contractors based on political affiliation rather than competence." A combination of "politically inspired gangsters, heroic bandits, and left-wing 
gunmen" have "robbed banks, challenged the security forces with hit-and-run tactics, and mocked the rule of the two parties" (Harrigan 1998, 17).

The origins of the violence goes back to the 1970s, when community leaders (known as "dons") were armed by the parties, given control of patronage, and used as enforcers in the turf wars that divided the country. In the case of Jamaica, political disorder clearly results from bad governance, rather than from such common causes of political instability as racial, religious, or tribal differences.

Because liberal democracy has taken a dysfunctional form in Jamaica, it has intensified corruption, contrary to the conventional assumption. At the same time, there is not enough classical (consensus-building) democracy here to prevent persistent mismanagem the economy manifesting itself in slow growth, budgetary shortfalls, inflation, and $y$ payable $c$. (see USAID 2006). Parastatals have been used by the government to undermim econon because they are "monitored only in exceptional circumstances." More or, ba cre it unions, and insurance companies remain under-capitalized, under-s pervis d, an cuerregulated, with the public usually kept in the dark about this mismanzs nnt

The country continues to suffer from a fiscal deficit of \$ 23 inflat on rate of $13 \%$, a massive debt burden, a growth rate of below $1.5 \%$ overvalu crency, high interest rates, and other barriers to trade and investment ont ere is me e evidence of classical democracy, Jamaica will certainly be unable t scape h overty, violence, and misery, even though, culturally, it may remain more ey citing than purita cal and authoritarian Singapore.

\section{Implications:}

What we are left with in this comparingapore and Jamaica in regard to Lord Acton's assertion is the following: (1) politic $1 \mathrm{p}$ m persuasive (i.e., legitimate), is not necessarily corruptive; (2) liberal (partisan, demoeracy tends to corrupt and lawless democracy, to corrupt absolutely ana author arjan regimes may recognize that controlling corruption is essential for thein itima $\mathrm{V}$ and ec nomic prosperity. However, more often than not, Lord Acton is correct, th the between autocracy and corruption.

This is because, pa cularly in countries (as noted earlier), leaders fear independent spheres of authority and ren comp cent subordinates as potentially undermining their authority or as ind a a ons o akness. They therefore surround themselves with loyalists, resulting in "pol icalinelasticits as explained in this article). But this is not inevitable. The authoritarian rimes East Asia (much as those of Nineteenth Century Europe) may tolerate a great deal or aption t not so much as to damage their political capacity, recognizing that, wh: cower corruption can also undermine power.

Refere

[1] Campos Jose Elgardo, Hilton L. Root, The Key to the Asian Miracle. Washington, DC: Brookings, 1996.

[2] Carothers Thomas, "Framing the Challenge." In Promoting the Rule of Law, ed. Thomas Carothers (Washington, DC: Carnegie Endowment for International Peace, 2006.

[3] Chadda Maya, "India: Between Majesty and Modernity." In The Struggle Against Corruption (109-139), ed., Roberta Ann Johnson. New York: Palgrave, 2004. 
[4] Dahl Robert A., Polyarchy: Participation and Opposition. New Haven: Yale University Press, 1971.

[5] Davies H. W. E., Town Planning Review 59 (1) (1988) 207-220.

[6] Diamond Larry, Can the Whole World Become Democratic? Public Lecture 12, September 2006. Available from the Institute for Policy Studies, www.ips.org

[7] Figueroa Mark, Amanda Sives, Commonwealth \& Comparative Politics 40(1) (2002) 81-108.

[8] Goehler Gerhard, "Constitution and Use of Power." In Power in Contemporary Politics (40-68), eds. Henri Goverde, Philip G. Cerny, Mark Haugaard and Howard Lentner. London: Sage, 2000.

[9] Global Advice Network 2008. China Country Profile. Available from www.business-anti-corruption.com.

[10] Gray O., "Predatory Politics and the Political Impasse in Jama ?, Axe, March, 90, 2003.

[11] Halperin Morton H., Joseph T. Siegle, Michael M. Wei steln he Demogratic Advantage: How Democracies Promote Prosperity Yeace. York and London: Routledge, 2005.

[12] Hamnett Steve, "Political Framework and Deve pmental Ob"ectives of Post-War Dutch Planning. In Public Planning in the Neth inds, eds. Ashok D. Dutt and Frank J. Costa. Oxford: Oxford University Presa 1985.

[13] Harrigan J., "Effects of the IMF and the Vor nk on Public Expenditure Accountability in Jamaica," Public Admi, is ation and Development 18 (1985) 1.

[14] Human and Social Developp ent oup. Vi lence and Urban Poverty in Jamaica: Breaking the Cycle. Was ton, C: Worl Bank, 1997.

[15] Lee Kwan Yew, Fror cruird Id to First: The Singapore Story. Westport, CN: Praeger, 2000.

[16] Mann James, Th Chim antasy:How our Leaders Explain Away Chinese Repression London: Vik, 2007.

[17] Miller nan angr Yager, Kenya: The Quest for Prosperity. Boulder, CO: Westview

[18] Mutà Hussà "Nird World Quarterly 21(1) (2000) 313-38.

[19] he M. qel Haas. Westport, CT: Praeger, 1999.

[20] Norris atrin, Jamaica: The Search for an Identity. London: Oxford University Press, 1962.

[21] Pan Philip P., Out of Mao's Shadow: The Struggle for the Soul of a New China. New York: Simon \& Schuster, 2008.

[22] Sakwa Richard, Putin: Russia's Choice. London and New York: Routledge, 2004. 
[23] Toonen Theo A. J., Frank Hendriks, "The Embarrassment of Success: Institutional Underpinning of Polder Politics." In Polder Politics: The Re-Invention of Consensus Democracy in the Netherlands (265-90), eds. Frank Hendriks and Theo A. J. Toonen. Burlington, VT: Ashgate, 2001.

[24] USAID 2006. Jamaica. Washington, DC: USAID. Available from www.usaid.gov.

[25] U.S. Department of State 2004. Kenya Country Reports on Human Rights Practices 2003. Washington, DC: Bureau of Democracy, Human Rights, and Labor.

[26] Werlin Herbert H., The Mysteries of Development: Studies Using Political Elasticity Theory. Lanham, MD: University Press of America, 1998/2001.

[27] Wolin, Sheldon S., Politics and Vision: Continuity and Innovation in Wed Political Thought. Boston: Little, Brown, 1960.

[28] World Bank, World Bank Development Report 2000-2001. Washy gton, World Bank, 2001.

[29] World Bank, Kenya: A Policy Agenda to Restore Growth. y ashington World Bank, 2003.

[30] World Bank, The Road to Sustained Growth in Jamo Wash. on, DC: World Bank, 2004.

[31] Wrong Dennis H.. Power: Its Forms, Bases and Vses. New York: Harper and Row., 1979.

[32] Yusuf Shahid Dancing with Giants: Ch India, armun Global Economy. Washington, DC: World Bank, 2006.
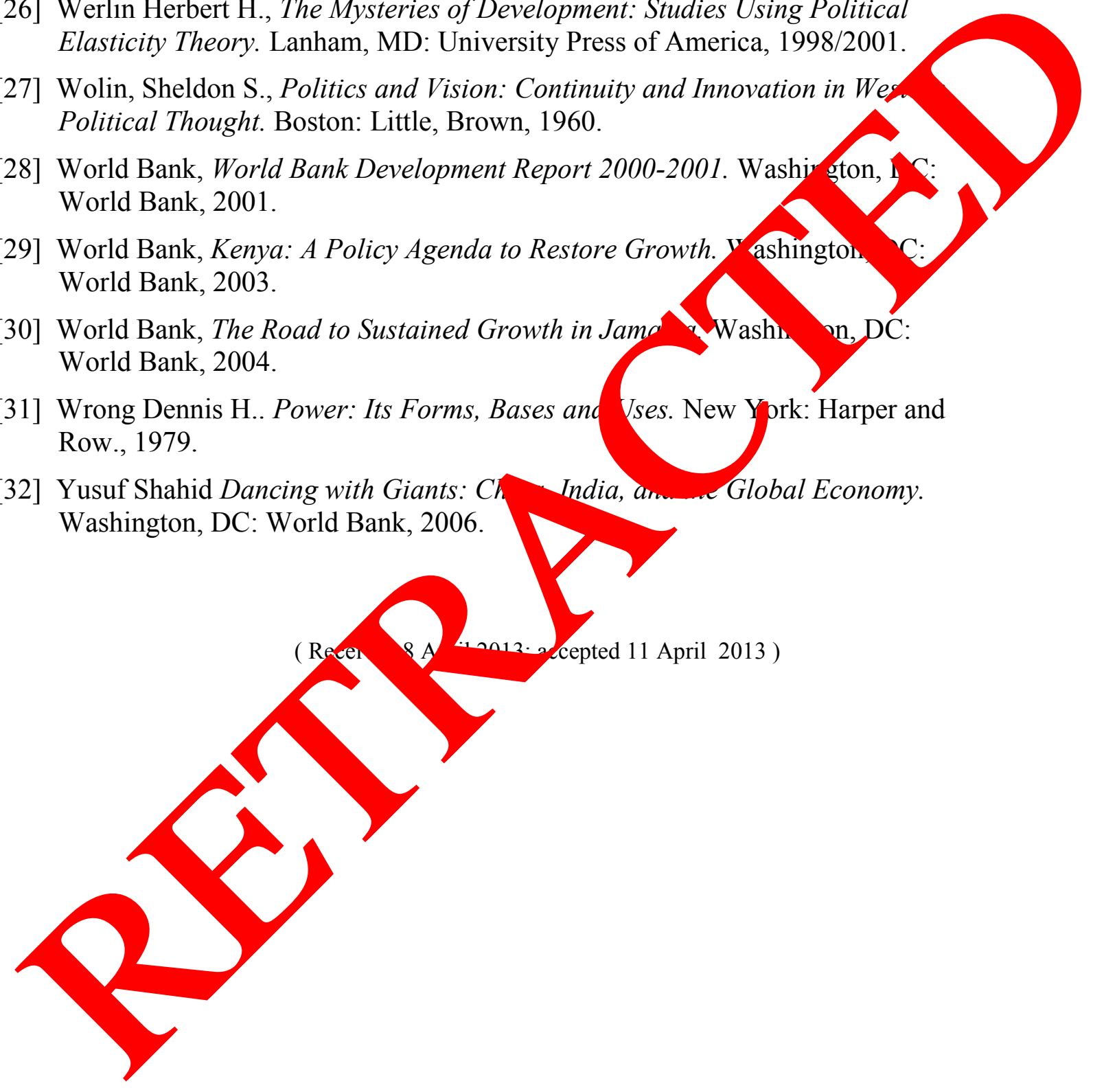